\title{
AN INTRODUCTION TO HEAVY METAL POLLUTION AND DIFFERENT TECHNOLOGIES AVAILABLE FOR REMEDIATION
}

\author{
Dharitri Ramanlal*, Rita Kumar*, Nirmal Kumar**, Rashmi Thakkar* \\ * Natubhai V. Patel College of Pure and Applied Sciences, Department of Biological and Environmental \\ Science, Vallabh Vidyanagar, India \\ ** Institute of Science \& Technology for Advanced Studies \& Research (ISTAR), P.G. Department of \\ Environmental Science \& Technology (EST), Vallabh Vidyanagar, India
}

corresponding author: Dharitri Ramanlal, e-mail: dharitripateleso@gmail.com

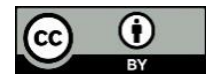

\begin{abstract}
This paper revises the fundamental facts about potentially toxic elements belonging to the group of heavy metals. The study highlights the ongoing soil pollution status affected by these nonbiodegradable elements, the basic characteristics of these metals that make them toxic, their mode of accumulation in different trophic levels, their toxic effect on human beings and the probable remediation technologies being used to remediate soils contaminated with heavy metal when the pollution problem has evolved. The technologies focused on solidification, soil washing, soil flushing, electro-kinetic remediation and phytoremediation are presented. The choice of the technology to be used for remediation depends on the condition of the soil and the extent of contamination. Conventional electro-kinetics is the most effective and rapid technology, but on the scale of ecosystem restoration, phytoremediation is an eco-friendly, green and cost-effective solution.
\end{abstract}

Keywords: potentially toxic elements, heavy metals, soil pollution and remediation

\section{INTRODUCTION}

\section{Soil pollution and its present status}

Soil is a complex structure which is made up of organic and inorganic matter. It balances the influx and efflux of several components via nutritive cycles allowing cooperative sustenance of several organisms on it [1]. The soil layer can become disturbed and polluted due to natural processes, such as soil erosion, floods, droughts and anthropogenic activities, like the addition of toxic pollutants through running industrial effluents, waste dumping, excavation activities, excessive use of metalcontaining fertilizers etc. [2]. According to the report, $25 \%$ of the global soil is highly degraded and $44 \%$ of the soil falls under the category of significantly degraded [3]. The soil acts as a collector of the pollutants which are 
further extracted by the plants growing over it, causing phytotoxicity to intolerant plant species and eventually entering the bodies of herbivores that feed on them, causing in turn various health ailments to organisms [4]. Thus, they accumulate in several trophic levels while traversing different levels in the food chain and food web. Amongst many pollutants, the metals are the most harmful due to their nonbiodegradable nature. The metal poisoning reported till date have mainly focused on lead $(\mathrm{Pb})$, chromium $(\mathrm{Cr})$, copper $(\mathrm{Cu})$, arsenic (As), cadmium $(\mathrm{Cd})$, cobalt (Co), mercury $(\mathrm{Hg})$, zinc $(\mathrm{Zn})$ and manganese $(\mathrm{Mn})$. Some of these metals also act as essential nutrients, but when their doses exceed the tolerance limits for the organisms the toxicity symptoms become evident.

\section{The definition and history of heavy metals}

Heavy metals have been present since evolution. Their ubiquity and certain characteristics have become worrying due to their occurrence in several forms in the environment. Heavy metals are categorized as the most toxic and lethal pollutants which have already caused many anthropogenic catastrophes and currently cause disruption in the normal functioning of ecosystems and food webs, especially since the advent of the industrial revolution [5]. The first incident that disturbed the humanity was Minamata disease which was one of the most serious cases of diseases resulted from environmental contamination of water by wastewater discharged from a nearby industrial plant containing Methyl mercury, which contaminated the marine life of the surrounding waters and affected and poisoned those who ate the affected fish and seafood [6]. Hence, the status of the pollution caused by heavy metals has become significant thereafter.

Currently, the main cause of their exploitation is due to several anthropogenic activities and the human exposure which has become fatal at elevated doses. The lithological evidence has shown that heavy metals are integral part of several rock structures and the high concentrations in the upwelling magma and the lava arising from the core of the earth finally making to the crust are their main natural sources. The heterogeneous localization of these elements in the crust was due to the movements of the tectonic plates, while some portion was stored in the form of sediments, underwater hills and mountains in the oceans. The primitive era also withholds prominent evidence of heavy metal deposition in many cases; several scientists proposed that during the burning of woods in winters high amount of these metals from the firewood was deposited on the walls and floors of ancient caves, thus very high concentrations of heavy metals in the caves have been recorded [7].

The current trend in technology has brought a general development, but at the same time it is not flawless because it caused unwarranted accumulation of many toxic pollutants. Due to overpopulation and uncontrollable pollution levels widespread in all the strata of the environment, it seems that there is a great vulnerability and uncertainty for the people. As long as the heavy metals were in a steadystate condition, their presence was not an issue, but their reappearance in various forms due to its economic importance to mankind resulted in their excessive use in the industrial sector that raised the issue of its exploitation and uncontrolled dumping [8].

The larger mass that faces the pressure of this pollution comprises the majority of the population from the developing countries which are already facing the problem of fulfilling basic needs of the population, and the technological need to deal with the pollutants is emerging as an economical challenge for the country itself. The World Health Organization (WHO) has reported that a major portion of almost $80 \%$ of industrial effluent and sewage waste is mixed with freshwater [9]. The gradual process of mixing effluents results in high levels of heavy metals in rivers, ponds and lakes, which disrupts the biology and geology of the home of several diverse species $[10,11]$. 
Heavy metals belong to the most toxic inorganic pollutant groups of the present century. The heavy metals are also called potentially toxic elements (PTE) due to their non-biodegradable nature [12]. However, their proper definition remains vague where the density and higher atomic weight are the criteria selected to classify and distinguish them. Current categorization based on the toxicity of heavy metals is unclear and nonspecific $[13,14]$. Research works carried out for a clearer classification show that the limits for their specific densities range from 3 to 7 $\mathrm{g} / \mathrm{cm}^{3}$ [15]. These heavy metals are nonbiodegradable, but are highly mobile under favourable conditions. Hence, they are deposited on soil by means of atmospheric deposition and penetrate into the deeper layers reaching the groundwater by infiltration. The other major collectors of heavy metals are the oceans where the maximum load is deposited in the sediments, while some make it to the biomass of the other higher form of vertebrates via the micro and macro inhabitants, finally upwelling it through the biotic as well as the abiotic zones [16]. According to available data from the ongoing researches of heavy metals concentration in various layers of soil, it is no surprise that there is a suspicion of the presence of heavy metals in the food on our plates. Continuous ignorant consumption of heavy-metal-rich vegetation grown near the source of pollution by residents causes a lot of health issues, and analysis of their blood will show a high concentration of heavy metals circulating in their systems, targeting sensitive tissues and organelles and resulting in their distorted functioning $[17,18]$.

\section{Importance of heavy metals for humans}

Heavy metals have great applicability in the industrial sector. Their abundant use, therefore, cannot be stopped. The doseresponse relationship of heavy metals concerning humans gives a true insight into the degree of lethality assessment of any substance. This limitation, unless reached, can cause minuscule biophysical mutations or disfigurement in the biological function, but cannot cause decease of any living organism; on the contrary, some of them are also required in certain quantities to carry out some enzymatic functions of the body [19, 20]. Hence, heavy metals play an important role in the biophysical systems of the living organisms. However, its excessive intake is cause for concern due to its high bioaccumulation potential with the tissues of the body, and are not removed by defecation or perspiration, which is the normal route for the ejection of toxicants from the human as well as the animal body. Hence, its presence in the body at higher concentrations can lead to an irreversible chronic condition [21]. It can be said that few heavy metals are functionally essential for some biological processes. Cobalt makes an integral part in the structure and composition of vitamin B12; however, at elevated levels within the human body it becomes carcinogenic [22, 23]. Iron is involved in the most crucial activities of oxygen transfer associated with transfer proteins, like haemoglobin and myoglobin, within the human body. However, when excessive accumulation of this metal is present, it begins to circulate through the body as unbound iron having a corrosive effect on the GI tract as well as other enzymatic fluids vital in maintaining the homeostasis of the bodily activities. Apart from biological applications, the isotopes of heavy metals are also used by many palaeontologists to study the ages of many fossils as well as sediments extracted from the underwater bodies or to find the age of stones formed due to volcanic activities based on the half-life of ${ }^{210} \mathrm{~Pb}$ [24]. Also, many studies suggest the use of heavy metals in the composition of ancient and traditional medicines practiced by several folk men [25]. Hence, heavy metals have many important roles in human life and several of their biological roles are presented in Table 1. 
Table 1. Sources of heavy metals and its adverse impact on organisms

\begin{tabular}{|c|c|c|c|c|}
\hline $\begin{array}{l}\text { Heavy } \\
\text { metal }\end{array}$ & Natural sources & Anthropogenic sources & Adverse impacts on organisms & References \\
\hline $\mathrm{Hg}$ & $\begin{array}{l}\text { Fossil fuels, within the } \\
\text { mineral cinnabar, volcanic } \\
\text { eruptions, forest fires } \\
\text { (present in trees and plants in } \\
\text { minute amount) etc. }\end{array}$ & $\begin{array}{c}\text { Mining, fossil fuel combustion, coal } \\
\text { washing, chlor-alkali, refining crude oil, } \\
\text { pulp and paper industry, medical waste, } \\
\text { sewage and sludge incineration, paints, } \\
\text { coatings, laboratory use, dental amalgams, } \\
\text { artisanal and small-scale gold mining, } \\
\text { breakage of fluorescent lamps, batteries } \\
\text { etc. }\end{array}$ & $\begin{array}{l}\text { Neurotoxic, muscle weakness, lack } \\
\text { of coordination, blurry vision, } \\
\text { impairment of speech, hearing, } \\
\text { reading, premature deaths etc. }\end{array}$ & {$[26-28]$} \\
\hline $\mathrm{Pb}$ & $\begin{array}{l}\text { Sea and salt lake aerosols, } \\
\text { forest fires, volcanic } \\
\text { eruptions, occur as lead- } \\
\text { sulphide in galena, the end } \\
\text { product of radioactive decay } \\
\text { of three radioactive } \\
\text { elements: uranium, thorium } \\
\text { and actinium etc. }\end{array}$ & $\begin{array}{c}\text { Plastic manufacturing, combustion, } \\
\text { incineration, fuels (additives), ceramic } \\
\text { glazes, crystal glassware, lead-jacketed } \\
\text { cables, ammunitions, paint manufacturing } \\
\text { etc. }\end{array}$ & $\begin{array}{l}\text { Resulting from constant exposure, } \\
\text { it lowers the intelligence quotient in } \\
\text { infants and causes behavioural } \\
\text { abnormalities, reduces the output of } \\
\text { haemoglobin, encephalopathy, lead } \\
\text { colic, increases blood pressure, } \\
\text { hypertension etc. }\end{array}$ & [29] \\
\hline $\mathrm{Cd}$ & $\begin{array}{l}\text { Volcanoes, weathering of } \\
\text { rocks, airborne soil particles, } \\
\text { sea spray, biogenic emission, } \\
\text { forest fires etc. }\end{array}$ & $\begin{array}{l}\text { Mining, smelting, refining sulphide ores of } \\
\text { zinc, lead and copper, iron and steel } \\
\text { production, cement production, } \\
\text { incineration, batteries, stationary fossil fuel } \\
\text { consumption, animal waste, atmospheric } \\
\text { fallout, logging and other wood waste, coal } \\
\text { ash, cadmium processing etc. }\end{array}$ & $\begin{array}{l}\text { Renal tubular damage, } \\
\text { osteoporosis, disturbances in } \\
\text { calcium metabolism, } \\
\text { hypercalciuria and formation of } \\
\text { stones in the kidney, lung cancer } \\
\text { and prostate cancer etc. }\end{array}$ & {$[30]$} \\
\hline As & $\begin{array}{l}\text { Volcanic activity, } \\
\text { low-temperature } \\
\text { volatilization, weathering, } \\
\text { geochemical reactions, } \\
\text { sedimentary rocks, pyrites } \\
\text { etc. }\end{array}$ & $\begin{array}{c}\text { Lead crystal glass } \\
\text { manufacturing, copper smelting, } \\
\text { combustion of coal (especially low-grade } \\
\text { brown coal), pesticides and herbicides, } \\
\text { landfills, mines, pit heaps, wastewater from } \\
\text { smelters, and arsenic-containing wood } \\
\text { preservatives etc. }\end{array}$ & $\begin{array}{l}\text { Acute renal damage, disturbed } \\
\text { heart function, mild } \\
\text { chronic poisoning causes fatigue } \\
\text { and loss of energy, more severe } \\
\text { symptoms include peripheral } \\
\text { vascular disorders ("black-foot } \\
\text { disease"), gastrointestinal } \\
\text { problems, kidney degeneration, } \\
\text { liver dysfunction, bone marrow } \\
\text { injury, and severe neuralgic pain } \\
\text { etc. }\end{array}$ & {$[31]$} \\
\hline $\mathrm{Cu}$ & $\begin{array}{l}\text { Ores, volcanic eruptions, } \\
\text { smelting, mining, } \\
\text { atmospheric fallout, } \\
\text { weathering of rocks, sea } \\
\text { sediments, forest fires etc. }\end{array}$ & $\begin{array}{l}\text { Coins, decorations, chemicals, laboratory } \\
\text { waste, vessels, batteries, welding, wire and } \\
\text { cables, metallurgy, electronic waste, } \\
\text { landfill sites, incineration, fertilizers and } \\
\text { pesticides, medicines etc. }\end{array}$ & $\begin{array}{l}\text { Irritation, nausea, vomiting, } \\
\text { dizziness, diarrhoea, cramps, } \\
\text { stomach ache, kidney, liver } \\
\text { problems etc. }\end{array}$ & {$[32]$} \\
\hline $\mathrm{Cr}$ & $\begin{array}{l}\text { Geochemical (volcanic } \\
\text { eruptions), ore mining, soils } \\
\text { and rock erosion, forest } \\
\text { wildfires etc. }\end{array}$ & $\begin{array}{l}\text { Emissions from chemical plants and } \\
\text { incineration facilities, effluents from } \\
\text { chemical plants, asbestos brakes, cement } \\
\text { dust, tattooing, textile manufacturing, } \\
\text { contaminated landfill, chrome alloy } \\
\text { production, chrome electroplating, } \\
\text { asbestos lining erosion, } \\
\text { road dust from catalytic converter erosion, } \\
\text { tobacco smoke, and topsoil and rocks. }\end{array}$ & $\begin{array}{l}\text { Chronic skin ulcer, respiratory } \\
\text { irritation, inflammation in lungs, } \\
\text { congestion and hyperaemia, } \\
\text { polyps of the upper respiratory } \\
\text { tract, trachea-bronchitis, } \\
\text { ulceration of the nasal mucosa, } \\
\text { hepatic problems, gastrointestinal } \\
\text { problems, cardiovascular issues etc. }\end{array}$ & {$[33,34]$} \\
\hline Co & $\begin{array}{l}\text { Soil, dust, seawater, } \\
\text { volcanic-eruptions and forest } \\
\text { fires. }\end{array}$ & $\begin{array}{l}\text { Burning coal and oil, aero-plane exhausts, } \\
\text { from industrial processes that use the } \\
\text { metal, as a paint drier, as a ground coat for } \\
\text { porcelain enamelling used on steel } \\
\text { bathroom - fixtures and large appliances, } \\
\text { diamond industry, construction industry } \\
\text { and as an ingredient of coloured pigments } \\
\text { etc. }\end{array}$ & $\begin{array}{c}\text { Cardiomyopathy, neurotoxic, } \\
\text { hypothyroidism etc. }\end{array}$ & {$[35,36]$} \\
\hline $\mathrm{Ni}$ & $\begin{array}{l}\text { Wind-blown dust carrying } \\
\text { nickel, weathering of rocks } \\
\text { and soils, volcanic } \\
\text { emissions, vegetation and } \\
\text { forest-fires. }\end{array}$ & $\begin{array}{l}\text { Used in making alloys, applications in the } \\
\text { metallurgical, chemical and food } \\
\text { processing industries as catalysts and } \\
\text { pigments, sewage sludge. }\end{array}$ & $\begin{array}{l}\text { Skin allergies, cancer of the } \\
\text { respiratory tract, lung fibrosis, } \\
\text { iatrogenic nickel } \\
\text { poisoning, nephrotoxicity. }\end{array}$ & {$[37,38]$} \\
\hline $\mathrm{Zn}$ & $\begin{array}{l}\text { Volcanic eruptions, forest } \\
\text { fires, sea spray and dust } \\
\text { storms. }\end{array}$ & $\begin{array}{l}\text { Solvents, cleaners, and other construction } \\
\text { materials paint, rubber, varnish, dyes, and } \\
\text { rust-proofing agents. }\end{array}$ & $\begin{array}{l}\text { Bronchopneumonia in infants, } \\
\text { respiratory toxicity, nausea, } \\
\text { abdominal pain, vomiting, ulcers, } \\
\text { constipation, tarry stools etc. }\end{array}$ & {$[39-41]$} \\
\hline
\end{tabular}




\section{REMEDIATION TECHNOLOGIES}

\section{Solidification}

Solidification is the process of retaining potentially toxic metals in contaminated soil, stopping their migration, and reducing the bioavailability by arresting them in compacted solid mass [42]. The materials used for this purpose include polyethylene, molten bitumen, emulsified asphalt and Portland cement [43]. It might take a few weeks or months to complete this process. It takes an average of 1.1 month or even less for the operational implementation of this method [44]. There are two types of solidification, in situ which is done at the site of contamination itself and ex-situ where the contaminated soil is transported at another site and treated there. In situ solidification is preferred more as it is less labour intensive and eliminates the steps of excavating and transportation which increases the treatability cost [45]. But it becomes challenging when the site is made of bedrock, rocky boulders, clayey in nature, which prevents the proper mixing of the binding solution with a site to be remediated [46]. This method is recommended only for soils contaminated with cationic metals [47]. It has been reported that $\mathrm{Hg}$, As and $\mathrm{Cr}$ cannot be treated with this methodology [45]. The metals once solidified do not leach out further thereby preventing groundwater pollution as shown in Figure 1. The use of cement is considered to be cheaper compared to other binding agents [42].

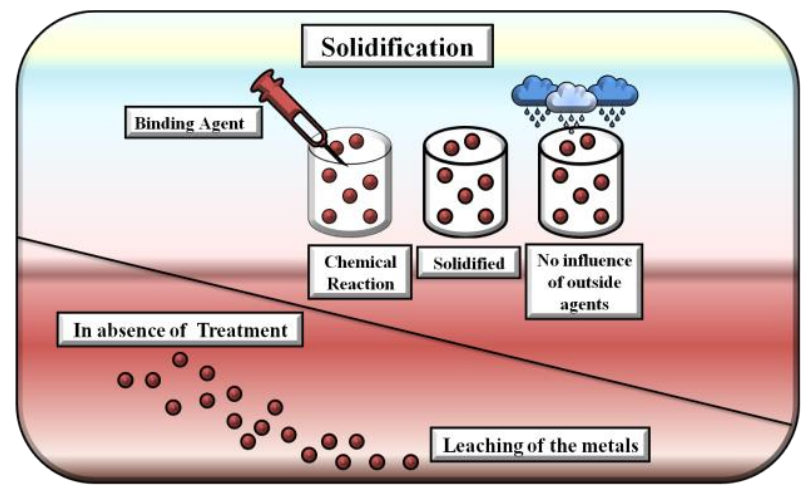

Figure 1. The process of solidifying the contaminants (metals) in polluted soil [48]

\section{Soil washing}

Soil washing can remove heavy metals from contaminated soils by dissolving them in the wash solution [49]. The soil after washing can be reutilized for multipurpose economical as well as social benefits, such as farming, landfilling, construction and recreational activities [50]. It is mainly carried out via ex situ application; as an in situ approach without appropriate wash water accumulation arrangements can cause leaching of the wash water contaminating the groundwater [42]. Firstly, the excavated soil is brought to the place of operation after which it is crushed and screened to remove larger particles as shown in Figure 2. Under magnetic pressure, the magnetic materials are separated and the soil is finally treated with the washing solution under vibration or sonication [44]. The solutions used to wash the soil are: $\mathrm{HCl}, \mathrm{H}_{2} \mathrm{SO}_{4}, \mathrm{HNO}_{3}$, $\mathrm{H}_{2} \mathrm{PO}_{4}, \quad \mathrm{CH}_{3} \mathrm{COOH}$ etc. [51]. Also, the chelating agents, like EDTA, EDDS, DTPA and NTA are widely used [52]. Clay soil and soil with a larger humic content cannot be treated with this approach. In general, soil washing is considered to be cheap if targeted for large contaminated areas, but it does not destroy the pollutants, it only transfers it from one medium to the other [42]. Further, these heavy metals extracted in the wash solution can be re-extracted for use [53]. The drawback of this method is that a portion of the solution used for washing the soil as well as a large portion of heavy metals remains in the soil as a residual [54].

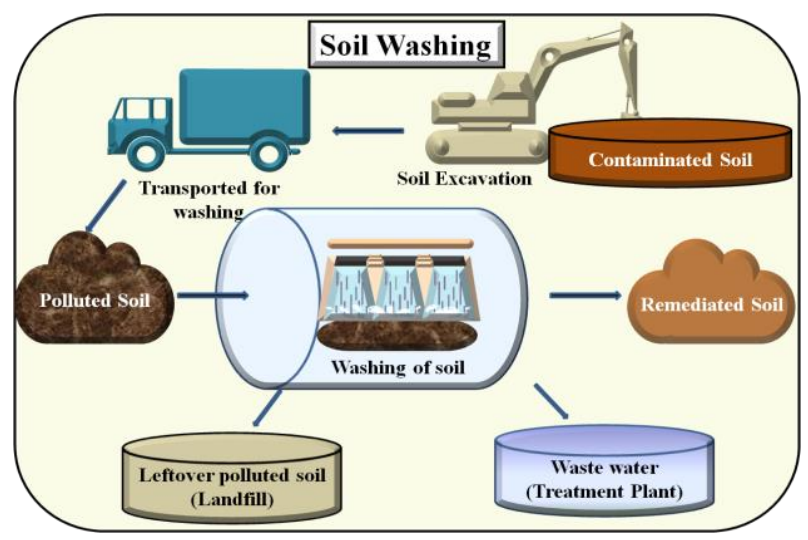

Figure 2. The ex situ washing the soil contaminated with heavy metals [48] 


\section{Soil flushing}

An in situ approach to clean up the heavy metal contaminated site using an appropriate solution is known as soil flushing [55]. The aqueous solution or simply water is allowed to pass through the contaminated soil and the eluent is collected and pumped up to the ground via appropriate channels which are further treated for reuse or disposed of in landfill sites [56]. For the collection of the treated solution, proper extraction well is engineered so the fluid can be extracted completely [57]. The wastewater is treated separately from heavy metals and reused again for flushing as shown in Figure 3. In this process, extreme care is taken in selecting the additives which are less harmful to the soil. Amongst several solutions used to date, EDTA has been the most relevant and successful for heavy metals extraction compared to the other organic and inorganic solvents [58]. The literature available shows the technological utility in flushing out heavy metals, such as $\mathrm{Cd}, \mathrm{Cr}, \mathrm{Cu}$ and $\mathrm{Zn}$ [59, 60]. Soil flushing becomes successful and cost-effective if the soil to be treated is permeable in nature to let the solution pass readily through the layers of soil [42]. This technique is less effective in soils with high cation exchange capacity (CEC) and high organic matter [61]. Practically this method has wide applications in treating the organic pollutants than the inorganic pollutants.

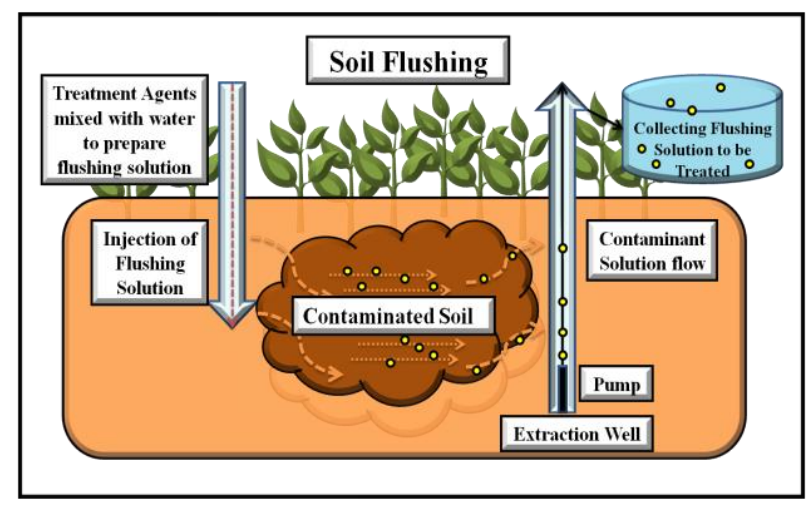

Figure 3. The in situ flushing the soil contaminated with heavy metals [62]

\section{Electro-kinetic}

This process is also referred to as electroremediation [63]. This technology has been functional since the late 1980s for remediating soil contaminated with heavy metals [64]. With this method, a low-intensity direct current is applied between the anode and the cathode inserted inside the contaminated soil at the site [65]. It is possible to carry out this process in situ as well as ex situ. The major drawback of this method is the change in the $\mathrm{pH}$ which eventually changes the migration of the negatively charged anions towards the positive anode and positively charged cations towards the negatively charged cathode [66]. As they migrate towards the respective electrodes based on charge, the contaminants may further be removed by processes such as precipitation, electroplating, pumping near the electrode or complexing with exchange resins as shown in Figure 4. This electro-kinetics methodology of soil remediation can be used to clean polluted soils up to great depths. In certain cases, one central cathode is arranged among several anodes in its surrounding. The ideal distance between the two electrodes to be maintained is $10 \mathrm{~m}$ with an approximate depth of $12 \mathrm{~m}$ and voltage variation from 20 to 100 $\mathrm{V} / \mathrm{m}$ [49]. This method also works for clay soil and soils with low permeability, unlike soil washing and soil flushing [67]. Its application is mainly in soils highly saturated with water.

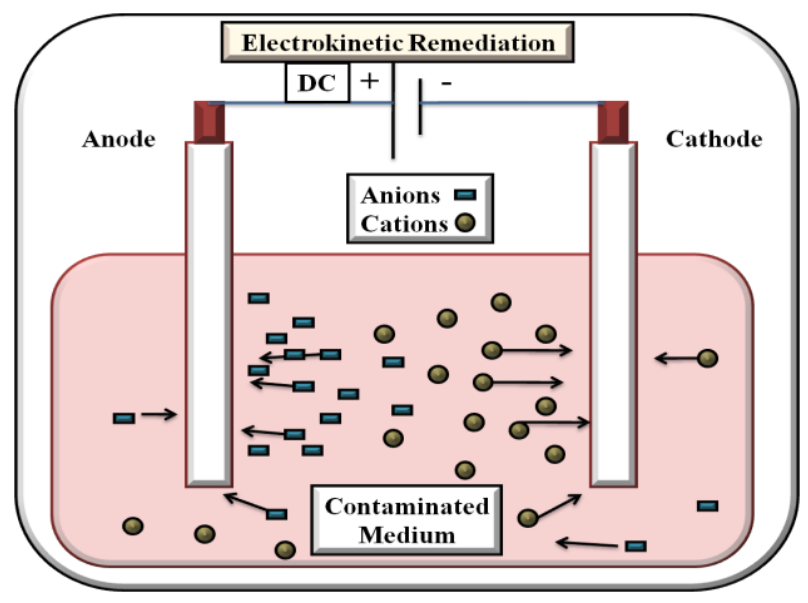

Figure 4. The electro-remediation of heavy metal polluted soil [68] 


\section{Phytoremediation}

Phytoremediation, also referred as green remediation or vegetative remediation, which is also defined as in situ remediation technology that uses plants and associated microorganisms to sequester, contain, or change environmental contaminants to innocuous state [69]. It can be carried out ex situ also, but it is not much preferred compared to in situ. It is applicable for both organic and inorganic contaminants where the autotrophs can degrade organic compounds whereas it can extract and stabilize inorganic metals in its aboveground biomass [59]. There are few plants which exhibit higher metal accumulating capacity; therefore, they can be used for cleaning up soils contaminated with toxic heavy metals [70]. Phytoremediation is considered to be a low-cost as well as ecologically sound way to remediate metal pollutants from contaminated site and it is receiving prior consideration compared to other technologies over the last few decades [69]. It is a remarkable approach which offers site remediation and conservation of the biological and physical composition of soils with a probability of re-extracting metals from the biomass of plants which is also termed as phytomining of metals [71]. Phytoremediation has three different mechanisms for remediating heavy metals contaminated soils, which includes phytoextraction, phytostabilization and phytovolatilization, as shown in Figure 5.

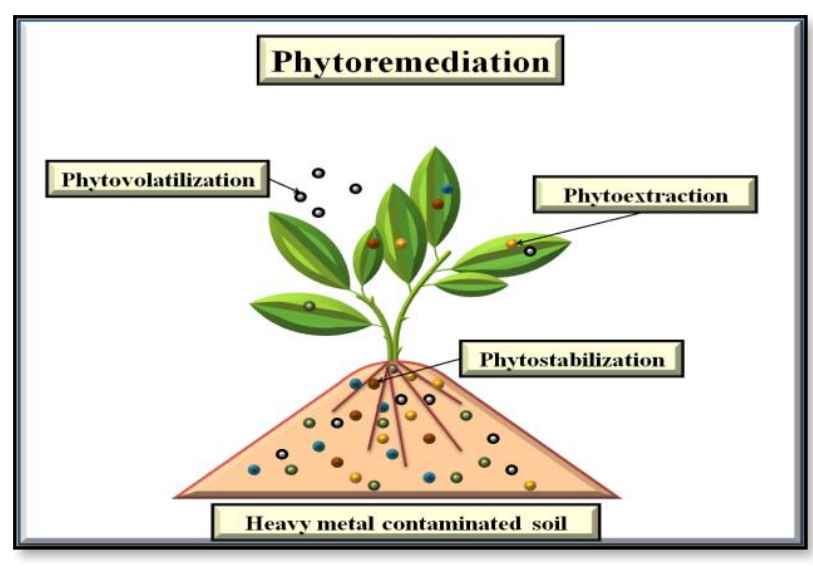

Figure 5. Phytoremediation for heavy metals and its mechanisms [68]
In phytoextraction the metals are extracted by the plant roots and further translocated to shoots, after which the above-ground parts are harvested to remove the sequestered contaminants [72]. Some of the plant species, popular as hyper accumulators, are Brassica junica $(\mathrm{Pb}$ and $\mathrm{Zn})$, Thlaspicaerulescens $(\mathrm{Cd}$ and $\mathrm{Zn})$, Alyssum sp.(Ni) and a grass variety Vetiveriazizaniodes ( $\mathrm{Zn}) \quad$ etc. Phytostabilization is also referred as in-place inactivation and it is primarily concerned to immobilize the heavy metals from the soil, sediment and sludges by the use of certain plants [73]. This technology arrests the metals near the root regions preventing it from leaching to the groundwater thereby preventing pollution and accumulation of heavy metals in organisms via drinking water. It also restricts the transport of metals via wind to other land surface or surface water reservoirs. This technique is used to stabilize $\mathrm{Cd}, \mathrm{Pb}, \mathrm{Cr}, \mathrm{As}, \mathrm{Cu}$ and $\mathrm{Zn}$ [72]. Phytovolatilization process involves extracting the metals and converting them or breaking them down to less harmful form and liberate in the atmosphere. Such a transformation has been reported only for $\mathrm{Hg}$ converting it to elemental form and recovered through the extraction process. Species such as N. tabacum and Arabidopsis thaliana have shown positive outcomes during an experimental setup. This process is mainly used for phytoremediation of organic compounds [74].

The advantages of phytoremediation over other conventional remediation approaches are:

a) it is economically viable and can be carried out using simple agricultural tools readily available,

b) it is less disruptive to the surrounding environment,

c) there is no need for a treatment site or a disposal site,

d) it favours public interest as it is aesthetically pleasing then other traditional methods,

e) no excavation and transport of polluted soil is required if carried out on site, 
thereby reducing the risk of spreading and contamination, and

f) it can treat sites polluted with a variety of pollutants.

\section{CONCLUSION}

The heavy metal pollution is a serious matter. Dealing with it requires an appropriate and eco-friendly approach because it is nonbiodegradable in nature and has an innate characteristic to bio-magnify in the species at various trophic levels. Several technologies, as mentioned above in this research paper, are available, but one that is suitable for a particular contaminated soil should be selected by focusing on the contaminated medium, economic feasibility and eco-friendliness. All of these available technologies have their advantages and disadvantages. India is a developing country; hence an eco-friendly approach is required in dealing with the waste as well as with the contaminants. Phytoremediation is one such suitable green technology because of its economic acceptability and eco-friendliness and its application should be boosted in the future as a sustainable remediation technology.

\section{REFERENCES}

[1] B. Floris, P. Galloni, F. Sabuzi, V. Conte, Metal systems as tools for soil remediation, Inorganica Chimica Acta 455(2017), 429-445. https://doi.org/10.1016/j.ica.2016.04.003

[2] N. Saberi, M. Aghababaei, M. Ostovar, H. Mehrnahad, Simultaneous removal of polycyclic aromatic hydrocarbon and heavy metals from an artificial clayey soil by enhanced electrokinetic method, Journal of environmental management 217(2018), 897-905. https://doi.org/10.1016/j.jenvman.2018.0 $\underline{3.125}$

[3] Food and Agriculture Organization of the United Nations, The state of the world's land and water resources for food and agriculture: Managing systems at risk, Earthscan, 2011.

[4] W. Ling, Q. Shen, Y. Gao, X. Gu, Z. Yang, Use of bentonite to control the release of copper from contaminated soils, Soil Research 45(2008) 8, 618623. https://doi.org/10.1071/SR07079

[5] Z. Zhao, J. Ball, P. Hazelton, Application of statistical inference for analysis of heavy metal variability in roadside soil, Water, Air, \& Soil Pollution 229(2018), Article number: 23. https://doi.org/10.1007/s11270-017$\underline{3675-\mathrm{z}}$

[6] M. Harada, Minamata disease: methylmercury poisoning in Japan caused by environmental pollution, Critical reviews in toxicology 25(1995) 1 , https://doi.org/10.3109/10408449509089 $\underline{885}$

[7] J.O. Nriagu, A history of global metal pollution, Science 272(1996) 5259, 223 224.

https://doi.org/10.1126/science.272.5259 .223

[8] H. Bing, Y. Wu, Z. Sun, S. Yao, Historical trends of heavy metal contamination and their sources in lacustrine sediment from Xijiu Lake, Taihu Lake Catchment, China, Journal of Environmental Sciences 23(2011) 10, 1671-1678.

https://doi.org/10.1016/S10010742(10)60593-1

[9] R. Usha, A. Vasavi, K. Thishya, S.J. Rani, P. Supraja, Phytoextraction of lead from industrial effluents by sunflower (Helianthus Annuus.L), Rasayan Journal of Chemistry 4(2011) 1, 8-12.

[10] A.A. Bawuro, R.B. Voegborlo, A.A. Adimado, Bioaccumulation of heavy metals in some tissues of fish in Lake Geriyo, Adamawa State, Nigeria, Journal of environmental and public health 2018(2018), Article ID 1854892. https://doi.org/10.1155/2018/1854892

[11] S. Rajeshkumar, X. Li, Bioaccumulation of heavy metals in fish species from the Meiliang Bay, Taihu Lake, China, 
Toxicology reports 5(2018), 288-295. https://doi.org/10.1016/j.toxrep.2018.01. 007

[12] B.E. Ifon, A.C.F. Togbé, L.A.S. Tometin, F. Suanon, A. Yessoufou, Metal-Contaminated Soil Remediation: Phytoremediation, Chemical Leaching and Electrochemical Remediation, in: Metals in Soil - Contamination and Remediation, ed. Z.A. Begum, IntechOpen, 2019, 1-20.

[13] K.J. Appenroth, What are "heavy metals" in plant sciences? Acta Physiologiae Plantarum 32(2010) 4, 615619. https://doi.org/10.1007/s11738-0090455-4

[14] R. Kumar, D. Bhatia, R. Singh, S. Rani, N.R. Bishnoi, Sorption of heavy metals from electroplating effluent using immobilized biomass Trichoderma viride in a continuous packed-bed column, International Biodeterioration \& Biodegradation 65(2011) 8, 1133-1139. https://doi.org/10.1016/j.ibiod.2011.09.0 03

[15] J.H. Duffus, "Heavy metals" a meaningless term? (IUPAC Technical Report), Pure and applied chemistry 74(2002) 5, 793-807. https://doi.org/10.1351/pac20027405079 $\underline{3}$

[16] M.M. Serbaji, C. Azri, K. Medhioub, Anthropogenic contributions to heavy metal distributions in the surface and sub-surface sediments of the northern coast of Sfax, Tunisia, International Journal of Environmental Research 6(2012) 3, 613-626. https://doi.org/10.22059/ijer.2012.531

[17] R.C. Tasrina, A. Rowshon, A.M.R. Mustafizur, I. Rafiqul, M.P. Ali, Heavy metals contamination in vegetables and its growing soil, Journal of Environmental Analytical Chemistry 2(2015) 3, 1-6, doi: 10.4172/23802391.1000142.

[18] R. Patcharin, S. Intamat, B. Tengjaroenkul, L. Neeratanaphan, Bioaccumulation of heavy metals in local edible plants near a municipal landfill and the related human health risk assessment, Human and Ecological Risk Assessment: An International Journal 25(2019) $\quad 7, \quad 1760-1772$. https://doi.org/10.1080/10807039.2018.1 $\underline{473755}$

[19] R.A. Goyer. T.W. Clarkson, Toxic effects of metals, Casarett and Doull's toxicology: the basic science of poisons 5(1996), 696-698.

[20] S.S. Singh, Soil fertility and nutrient management, Kalyani Publishers, 2011.

[21] M. Jaishankar, T. Tseten, N. Anbalagan, B.B. Mathew, K.N. Beeregowda, Toxicity, mechanism and health effects of some heavy metals, Interdisciplinary toxicology 7(2014) 2, 60-72. https://doi.org/10.2478\%2Fintox-20140009

[22] Y. Ge, Z. Li, Application of lignin and its derivatives in adsorption of heavy metal ions in water: a review, ACS Sustainable Chemistry \& Engineering 6(2018) 5, 7181-7192. https://doi.org/10.1021/acssuschemeng.8 b01345

[23] M. Valko, H. Morris, M.T.D. Cronin, Metals, toxicity and oxidative stress, Current medicinal chemistry 12(2005) 10 ,

1161-1208. https://doi.org/10.2174/09298670537646 $\underline{35}$

[24] G.L. Yuan, C. Liu, L. Chen, Z. Yang, Inputting history of heavy metals into the inland lake recorded in sediment profiles: Poyang Lake in China, Journal of hazardous materials 185(2011) 1, 336-345.

https://doi.org/10.1016/j.jhazmat.2010.0 9.039

[25] E. Ernst, Heavy metals in traditional Indian remedies, European journal of clinical pharmacology 57(2002) 12, 891896. https://doi.org/10.1007/s00228-0010400-y

[26] K. Sundseth, J.M. Pacyna, E.G. Pacyna, N. Pirrone, R.J. Thorne, Global sources and pathways of mercury in the context of human health, International journal of environmental research and public health 14(2017) 1, Article number: 105. https://doi.org/10.3390/ijerph14010105 
[27] C.T. Driscoll, R.P. Mason, H.M. Chan, D.J. Jacob, N. Pirrone, Mercury as a global pollutant: sources, pathways, and effects, Environmental science \& technology 47(2013) 10, 4967-4983. https://doi.org/10.1021/es305071v

[28] M. Cohen, R. Artz, R. Draxler, P. Miller, L. Poissant, D. Niemi, D. Ratte et al, Modelling the atmospheric transport and deposition of mercury to the Great Lakes, Environmental Research 95(2004) 3, 247-265. https://doi.org/10.1016/j.envres.2003.11. 007

[29] G. Naja, B. Volesky, The mechanism of metal cation and anion biosorption, in: Microbial biosorption of metals, ed: P. Kotrba, M. Mackova, T. Macek, Springer, 2011, 19-58. https://doi.org/10.1007/978-94-0070443-5_3

[30] I. Stupak, A. Asikainen, M. Jonsell, E. Karltun, A. Lunnan, D. Mizaraite, K. Pasanen et al, Sustainable utilisation of forest biomass for energy - Possibilities and problems: Policy, legislation, certification, and recommendations and guidelines in the Nordic, Baltic, and other European countries, Biomass and Bioenergy 31(2007) 10, 666-684. https://doi.org/10.1016/j.biombioe. 2007. $\underline{06.012}$

[31] Y.C. Jang, Y. Somanna, H. Kim, Source, distribution, toxicity and remediation of arsenic in the environment - a review, International Journal of Applied Environmental Sciences 11(2016) 2, 559-581.

[32] A. Dorsey, L. Ingerman, Toxicological profile for copper, 2004. https://www.atsdr.cdc.gov/toxprofiles/tp 132.pdf

[33] A. Bielicka, I. Bojanowska, A. Wisniewski, Two Faces of Chromium Pollutant and Bioelement, Polish Journal of environmental studies 14(2005) 1, 510.

[34] P.M. Oana, Chromium impact on marine ecosystem, Bulletin of University of Agricultural Sciences and Veterinary Medicine Cluj - Napoca, Veterinary
Medicine 63(2006) 1-2, 379-384. http://doi.org/10.15835/buasvmcnvm:63:1-2:2516

[35] L. Leyssens, B. Vinck, C.V.D. Straeten, F. Wuyts, L. Maes, Cobalt toxicity in humans - A review of the potential sources and systemic health effects, Toxicology 387(2017), 43-56. https://doi.org/10.1016/j.tox.2017.05.015

[36] J. Li, X. Wang, G. Zhao, C. Chen, Z. Chai, A. Alsaedi, T. Hayat, X. Wang, Metal-organic framework-based materials: superior adsorbents for the capture of toxic and radioactive metal ions, Chemical Society Reviews 47(2018) 7, 2322-2356. https://doi.org/10.1039/C7CS00543A

[37] M. Cempel, G. Nikel, Nickel: A review of its sources and environmental toxicology, Polish journal of environmental studies 15(2006) 3, 375382.

[38] V. Bencko, Nickel: a review of its occupational and environmental toxicology, Journal of hygiene, epidemiology, microbiology, and immunology 27(1983) 2, 237-247.

[39] N. Roney, Toxicological profile for zinc, Agency for Toxic Substances and Disease Registry, 2005.

[40] K.A. Molchan, An Ethical Model for Mandatory Reporting to Avoid Preventable Adverse Harm in Health Care, Doctoral dissertation, Duquesne University, Retrieved from https://dsc.duq.edu/etd/1746, 2018.

[41] L.M. Plum, L. Rink, H. Haase, The essential toxin: impact of zinc on human health, International journal of environmental research and public health 7(2010) 4,1342-1365. https://doi.org/10.3390/ijerph7041342

[42] J. Bech, M.M. Abreu, H.T. Chon, N. Roca, Remediation of potentially toxic elements in contaminated soils, in: PHEs, Environment and Human Health, ed: C. Bini, J. Bech, Springer, 2014, 253-308. https://doi.org/10.1007/978-94017-8965-3_7

[43] S. Kuppusamy, T. Palanisami, M. Megharaj, K. Venkateswarlu, R. Naidu, 
Ex-situ remediation technologies for environmental pollutants: a critical perspective, in: Reviews of Environmental Contamination and Toxicology, Volume 236, ed: P. de Voogt, Springer, 2016, 117-192. https://doi.org/10.1007/978-3-31920013-2_2

[44] L. Liu, W. Li, W. Song, M. Guo, Remediation techniques for heavy metalcontaminated soils: principles and applicability, Science of the Total Environment 633(2018), 206-219. https://doi.org/10.1016/j.scitotenv.2018. $\underline{03.161}$

[45] C.N. Mulligan, R.N. Yong, B.F. Gibbs, Remediation technologies for metalcontaminated soils and groundwater: an evaluation, Engineering geology 60(2001) 1-4, 193-207. https://doi.org/10.1016/S00137952(00)00101-0

[46] B.H. Jasperse, C.R. Ryan, Stabilization and fixation using soil mixing, in: Grouting, Soil Improvement and Geosynthetics, ed: R.H. Borden, R.D. Holtz, I. Juran, American Society of Civil Engineers, 1992, 1273-1284.

[47] G. Dermont, M. Bergeron, G. Mercier, M. Richer-Laflèche, Soil washing for metal removal: a review of physical/chemical technologies and field applications, Journal of hazardous materials 152(2008) 1, 1-31. https://doi.org/10.1016/j.jhazmat.2007.1 0.043

[48] S. Gitipour, M. Hedayati, E. Madadian, Soil washing for reduction of aromatic and aliphatic contaminants in soil, CLEAN - Soil, Air, Water 43(2015) 10, 1419-1425.

https://doi.org/10.1002/clen.201100609

[49] H. Meuser, Soil remediation and rehabilitation: Treatment of contaminated and disturbed land, Springer, 2013. https://doi.org/10.1007/978-94-007$\underline{5751-6}$

[50] D. Hou, A. Al-Tabbaa, J. Hellings, Sustainable site clean-up from megaprojects: lessons from London
2012, Proceedings of the Institution of Civil Engineers - Engineering Sustainability $168(2015) \quad 2, \quad 61-70$. https://doi.org/10.1680/ensu.14.00025

[51] K.K. Fedje, O. Modin, A-M. Strömvall, Copper recovery from polluted soils using acidic washing and bioelectrochemical systems, Metals 5(2015) 3,1328-1348. https://doi.org/10.3390/met5031328

[52] Z. Yang, C. Dong, C. Chen, Y. Sheu, C. Kao, Using poly-glutamic acid as soilwashing agent to remediate heavy metalcontaminated soils, Environmental Science and Pollution Research 25(2018) 6, 5231-5242. https://doi.org/10.1007/s11356-0179235-7

[53] C. Su, L. Jiang, W. Zhang, A review on heavy metal contamination in the soil worldwide: Situation, impact and remediation techniques, Environmental Skeptics and Critics 3(2014) 2, 24-38.

[54] X. Zhai, Z. Li, B. Huang, N. Luo, M. Huang, Q. Zhang, G. Zeng, Remediation of multiple heavy metal-contaminated soil through the combination of soil washing and in situ immobilization, Science of the Total Environment 635(2018), 92-99. https://doi.org/10.1016/j.scitotenv.2018. $\underline{04.119}$

[55] A. Jankaite, S. Vasarevičius, Remediation technologies for soils contaminated with heavy metals, Journal of environmental engineering and landscape management 13(2005) 2, 109113.

https://doi.org/10.1080/16486897.2005.9 636854

[56] R. Parry, Agricultural phosphorus and water quality: A US Environmental Protection Agency perspective, Journal of Environmental Quality 27(1998) 2, 258-261.

https://doi.org/10.2134/jeq1998.0047242 5002700020003x

[57] F.I. Khan, T. Husain, R. Hejazi, An overview and analysis of site remediation technologies, Journal of environmental management 71(2004) 2, 
95-122.

https://doi.org/10.1016/j.jenvman.2004.0 2.003

[58] R.A. Wuana, F.E. Okieimen, Heavy metals in contaminated soils: a review of sources, chemistry, risks and best available strategies for remediation, International Scholarly Research Notices 2011(2011), Article ID 402647, https://doi.org/10.5402/2011/402647.

[59] D.C.W. Tsang, W. Zhangand, I.M.C. Lo, Copper extraction effectiveness and soil dissolution issues of EDTA - flushing of artificially contaminated soils, Chemosphere 68(2007) 2, 234-243. https://doi.org/10.1016/j.chemosphere.20 07.01 .022

[60] M. Šváb, M. Žilka, M. Müllerová, V. Kočí, V. Müller, Semi-empirical approach to modeling of soil flushing: Model development, application to soil polluted by zinc and copper, Science of the total environment 392(2008) 2-3, 187-197.

https://doi.org/10.1016/j.scitotenv.2007. 12.001

[61] S.C. Reed, R.W. Crites, E.J. Middlebrooks, Natural systems for waste management and treatment, $2^{\text {nd }}$ edition, McGraw-Hill, Inc., 1995.

[62] F. He, G. Jie, E. Pierce, P.J. Strong, H. Wang, L. Liang, In situ remediation technologies for mercury-contaminated soil, Environmental Science and Pollution Research 22(2015) 11, 81248147. https://doi.org/10.1007/s11356015-4316-y

[63] A.N. Alshawabkeh, Electrokinetic soil remediation: challenges and opportunities, Separation Science and Technology 44(2009) 10, 2171-2187. https://doi.org/10.1080/01496390902976 $\underline{681}$

[64] Y.B. Acar, R.J. Gale, A.N. Alshawabkeh, R.E. Marks, S. Puppala, M. Bricka, R. Parker, Electrokinetic remediation: basics and technology status, Journal of hazardous materials 40(1995) 2, 117-137. https://doi.org/10.1016/03043894(94)00066-P
[65] A. Figueroa, C. Cameselle, S. Gouveia, H.K. Hansen, Electrokinetic treatment of an agricultural soil contaminated with heavy metals, Journal of Environmental Science and Health, Part A 51(2016) 9, 691-700.

https://doi.org/10.1080/10934529.2016.1 170425

[66] ..., Transport and remediation of subsurface contaminants: colloidal, interfacial, and surfactant phenomena, ed: D.A. Sabatini, R.C. Knox, ACS Symposium Series 491, American Chemical Society, 1992.

[67] H-S. Helmisaari, M. Salemaa, J. Derome, O. Kiikkilä, C. Uhlig, T.M. Nieminen, Remediation of heavy metalcontaminated forest soil using recycled organic matter and native woody plants, Journal of environmental quality 36(2007) $\quad 4, \quad 1145-1153$. https://doi.org/10.2134/jeq2006.0319

[68] S. Khalid, S. Muhammad, N. Khan, B. Murtaza, I. Bibi, C. Dumat, A comparison of technologies for remediation of heavy metal contaminated soils, Journal of Geochemical Exploration 182(2017) Part B, 247-268. https://doi.org/10.1016/j.gexplo.2016.11. $\underline{021}$

[69] M.M. Lasat, Phytoextraction of toxic metals: a review of biological mechanisms, Journal of environmental quality 31(2002) 1, 109-120.

[70] M. Algreen, S. Trapp, A. Rein, Phytoscreening and phytoextraction of heavy metals at Danish polluted sites using willow and poplar trees, Environmental Science and Pollution Research 21(2014) 15, 8992-9001. https://doi.org/10.1007/s11356-0132085-Z

[71] H. Ali, E. Khan, M.A. Sajad, Phytoremediation of heavy metals Concepts and applications, Chemosphere 91(2013) 7, 869-881. https://doi.org/10.1016/j.chemosphere.20 13.01.075

[72] C.D. Jadia, M.H. Fulekar, Phytoremediation of heavy metals: 
Recent techniques, African journal of biotechnology 8(2009) 6, 921-928.

[73] ..., Introduction to phytoremediation, National Risk Management Research Laboratory, Office of Research and Development, US Environmental Protection Agency, 2000.

[74] C.L. Rugh, J.F. Senecoff, R.B. Meagher, S.A Merkle, Development of transgenic yellow poplar for mercury phytoremediation, Nature biotechnology 16(1998) $\quad 10, \quad 925-928$. https://doi.org/10.1038/nbt1098-925 